\title{
Combined Geoelectrical Approach DC and IP Methods in the Identification of the Mineralized Bodies Parallel to the NE-SW Tectonic Line of Kadei River: Case of Quartz or Pegmatite Gold Bearing Veins of Ngoura Subdivision (East Cameroon)
}

\author{
Daniel Hervé Gouet ${ }^{1}$, Stéphane Patrick Assembe ${ }^{2}$, Arsène Meying33, \\ Marcelin Bikoro Bialou ${ }^{4}$, Josué Kalaza Haskandi'5, Théophile Ndougsa-Mbarga ${ }^{6}$ \\ ${ }^{1}$ Department of Petroleum and Gas Explorations, Institute of Mines and Petroleum Industries, University of \\ Maroua, Maroua, Cameroun \\ ${ }^{2}$ Department of Physics, Faculty of Science, University of Bamenda, Bambili, Cameroon \\ ${ }^{3}$ Department of Applied Geophysics, Geology and Mining Exploitation College, University of Ngaoundéré, \\ Ngaoundéré, Cameroon \\ ${ }^{4}$ Department of Earth Sciences, Faculty of Science, University of Maroua, Maroua, Cameroun \\ ${ }^{5}$ Department of Earth Sciences, Faculty of Science, University of Ngaoundere, Ngaoundere, Cameroon \\ ${ }^{6}$ Department of Physics, Advanced Teacher's Training College, University of Yaounde I, Yaounde, Cameroon \\ Email: "gouetdanyl@yahoo.fr
}

Received 28 April 2016; accepted 8 July 2016; published 11 July 2016

Copyright (C) 2016 by authors and Scientific Research Publishing Inc.

This work is licensed under the Creative Commons Attribution International License (CC BY).

http://creativecommons.org/licenses/by/4.0/

(c) (i) Open Access

\begin{abstract}
A geophysical investigation of subsurface structures using the Syscal Junior 48 resistivity-meter was conducted in Ngoura subdivision (East Cameroon) following a combined geoelectrical direct current (DC) approach involving Resistivity and IP methods. This investigation was allowed to collect data on forty-five (45) profiling lines at three acquisition levels $(A B=100 \mathrm{~m}, \mathrm{MN}=10 \mathrm{~m} ; \mathrm{AB}=$ $200 \mathrm{~m}, \mathrm{MN}=20 \mathrm{~m}$ and $\mathrm{AB}=500 \mathrm{~m}, \mathrm{MN}=50 \mathrm{~m}$ ) and two electric panels $\mathrm{L1}$ and L4, using the Schlumberger array. Processing, modeling and interpretation of data collected using the Winsev, Res2Dinv and Surfer software helped in highlighting a conductive and strongly mineralized discontinuity in granite formations, which lined up with the NE-SW Kadei tectonic line. It extends beyond $100 \mathrm{~m}$ depth over an average width of $600 \mathrm{~m}$. The mineralization associated with this dis-
\end{abstract}

\footnotetext{
*Corresponding author.
}

How to cite this paper: Gouet, D.H., Assembe, S.P., Meying, A., Bikoro Bialou, M., Haskandi, J.K. and Ndougsa-Mbarga, T. (2016) Combined Geoelectrical Approach DC and IP Methods in the Identification of the Mineralized Bodies Parallel to the NE-SW Tectonic Line of Kadei River: Case of Quartz or Pegmatite Gold Bearing Veins of Ngoura Subdivision (East Cameroon). International Journal of Geosciences, 7, 891-903. http://dx.doi.org/10.4236/ijg.2016.77066 
continuity is identified by a high concentration of disseminated metalliferous minerals in quartz or pegmatite veins. The mining reconnaissance works in the study area and those of several authors have characterized this anomaly to a lode gold quartz or large pegmatite. The results of this study correlate with geological and tectonic data for the region marked by NE-SW Kadei tectonic line. Therefore, they confirm the reliability of a geoelectrical DC investigation method combining Resistivity and IP to the identification of ore bodies.

\section{Keywords}

Geoelectrical Investigation, Direct Current, IP Method, Resistivity, NE-SW Tectonic Line, Mineralized Body, Conductive Area

\section{Introduction}

Ore bodies' quest is a major concern for mining research. It assesses the mineral potential of the area. It is in this perspective that a geophysical investigation combining simultaneously IP and DC geoelectrical methods is conducted in Ngoura subdivision (East Cameroon). The approach of this study is to collect geoelectrical data along fifteen (15) profiles of E-W direction. The results (from resistivity and chargeability maps, resistivity and chargeability pseudo-sections and geological sections) from this campaign will make it possible to map and identify mineralized or gold-bearing bodies along the tectonic lines (fractures or shear zones) in the Ngoura subdivision. They will also reveal the reliability of a combined approach involving DC resistivity and IP geoelectrical methods in geophysical investigations.

\section{Geological and Tectonic Setting}

The area under study (Ngoura subdivision) is located between the latitudes $4.921^{\circ} \mathrm{N}$ and $5.054^{\circ} \mathrm{N}$, and the longitudes $14.296^{\circ} \mathrm{E}$ and $14.472^{\circ} \mathrm{E}$ (Figure 1 and Figure 2). This zone has a smooth relief with altitudes ranging between 700 and $800 \mathrm{~m}$ [1], and the structural trends in the area are NE-SW as broadly shown by the Kadei River flow path (Figure 2). The region is characterized [1] by a four-season tropical climate alternating two dry and rainy seasons. The savanna corresponds to the pertaining vegetation.

The Ngoura subdivision is located in the transition zone between the Pan African domain and the Congo Craton [2] [3], in the northern edge of the Cameroon faults' zone. This region of Cameroon is essentially made up of a Precambrian basement comprising metamorphic and magmatic rocks [2] [4]-[6]. These rocks belong to several epochs of the Precambrian and sometimes outcrop. These are mainly granites and migmatites rejuvenated during the Panafrican event [2] [3]. The Ngoura area is mainly made up of (Figure 1(a)):

- Biotite and muscovite quartzites, muscovite sericitic and conglomeratic quartzites, chlorite and sericite schists, paraamphibolites, orthogneisses, biotite gneisses and, pegmatites and quartz veins [7] constituting the Precambrian basal complex aged between 2.5 and 1.8 billion years. The mining activities of primary gold deposits in the study area (Figure 1(b)) show the real presence of pegmatite and quartz veins, main primary sources of gold deposit [1] [8].

- Plutonic and metamorphic formations [7] [9] made up of calc-alkaline granites with a porphyritic and alkali facies; granodiorites and syenites containing heterogeneous and undifferentiated biotite facies; quartz-diorites; micaschists, migmatites and embrechite gneisses;

- The main sedimentary rocks encountered are sandstones, sand, marl, limestones and, Paleozoic and Mesozoic conglomerates [7] [9].

Soils are red ferrallitic on the hills and plateaus and the geological cover of the study area can be seen in artisanal mining pits (Figure 1(b)). The geological section of the study area can be seen in the artisanal mining pits (Figure 1(b)) and borehole cross sections Pt01, Pt02, Pt03 and Pt04 (Figure 3) realized by a team of both Mining \& Geology Directorate and BRGM’s personnel from Cameroon [8].

The tectonic facts revealed that, the study area is characterized by four deformation phases D1-D4 [4] [6] [10]. The observed tectonic lines are directed SW-NE below, and turned to be SE-NW above the $4^{\circ} \mathrm{N}$ parallel (Figure 1). Previous geophysical studies [10] [11] have shown evidence of some buried faults directed W-E and have 


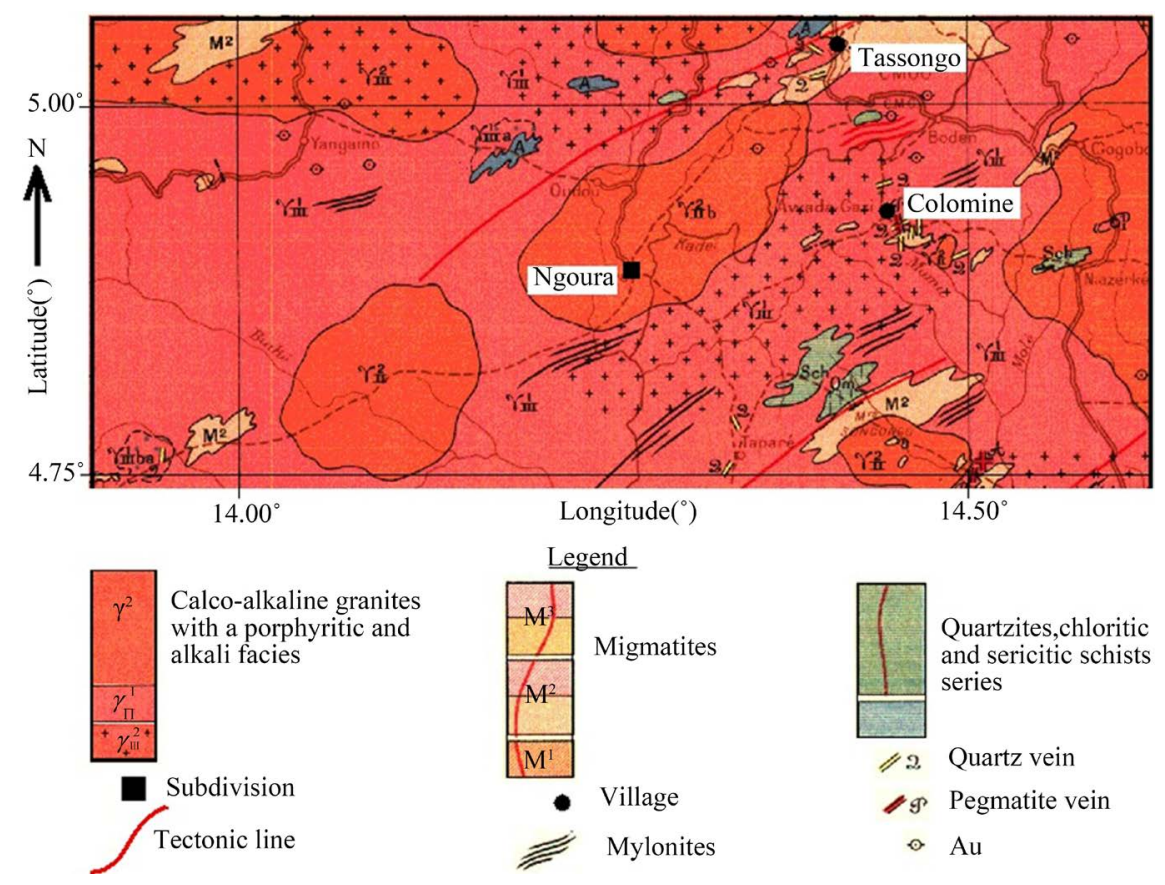

(a)

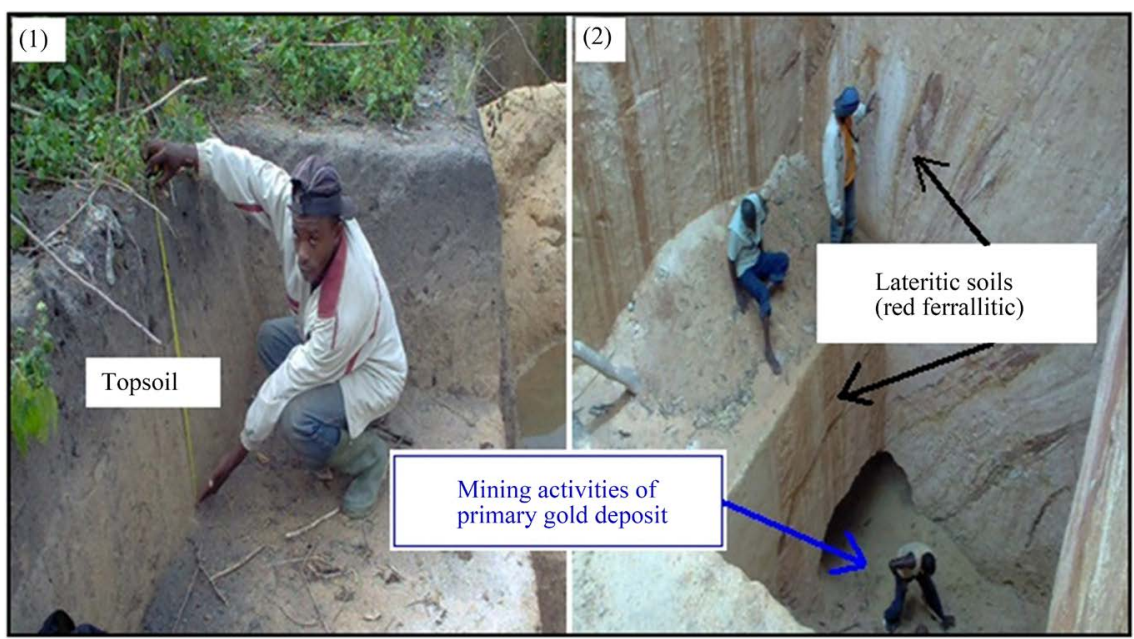

(b)

Figure 1. (a) Geological map of the study area; (b) Artisanal mining pit of primary gold deposits in the Colomine area, Ngoura subdivision.

confirmed tectonic nappes with a southern vergency. According to geological studies [6], the Pan-African deformation affecting the study area which appertains to the southern segment of the Neoproterozoic Fold Belt of Central Africa in Cameroon, is controlled by thrust tectonics and late strike-slip shear zones: the thrusting of the Pan-African Nappe over the Congo Craton (D2 deformation phase) is followed by a strike-slip shearing trending ENE-WSW (D3 deformation phase). During these stages, deforming conditions were ductile to brittle-ductile. The dominant structural features of the D3 phase are penetrative foliation steeply dipping $\mathrm{N}$ or $\mathrm{S}$, an associate ENE-WSW stretching lineation, and a N-S to NE-SW folding. Deformation criteria in the distinguished rock units indicate dextral shear. A dextral trans-pressional model is assumed [6] to explain the observed thrust and shear movements.

Few metallogenic data concerning mineralized bodies are available. This observation is the reason why the present study will combine direct current and induced polarization methods, in order to identify structural features 


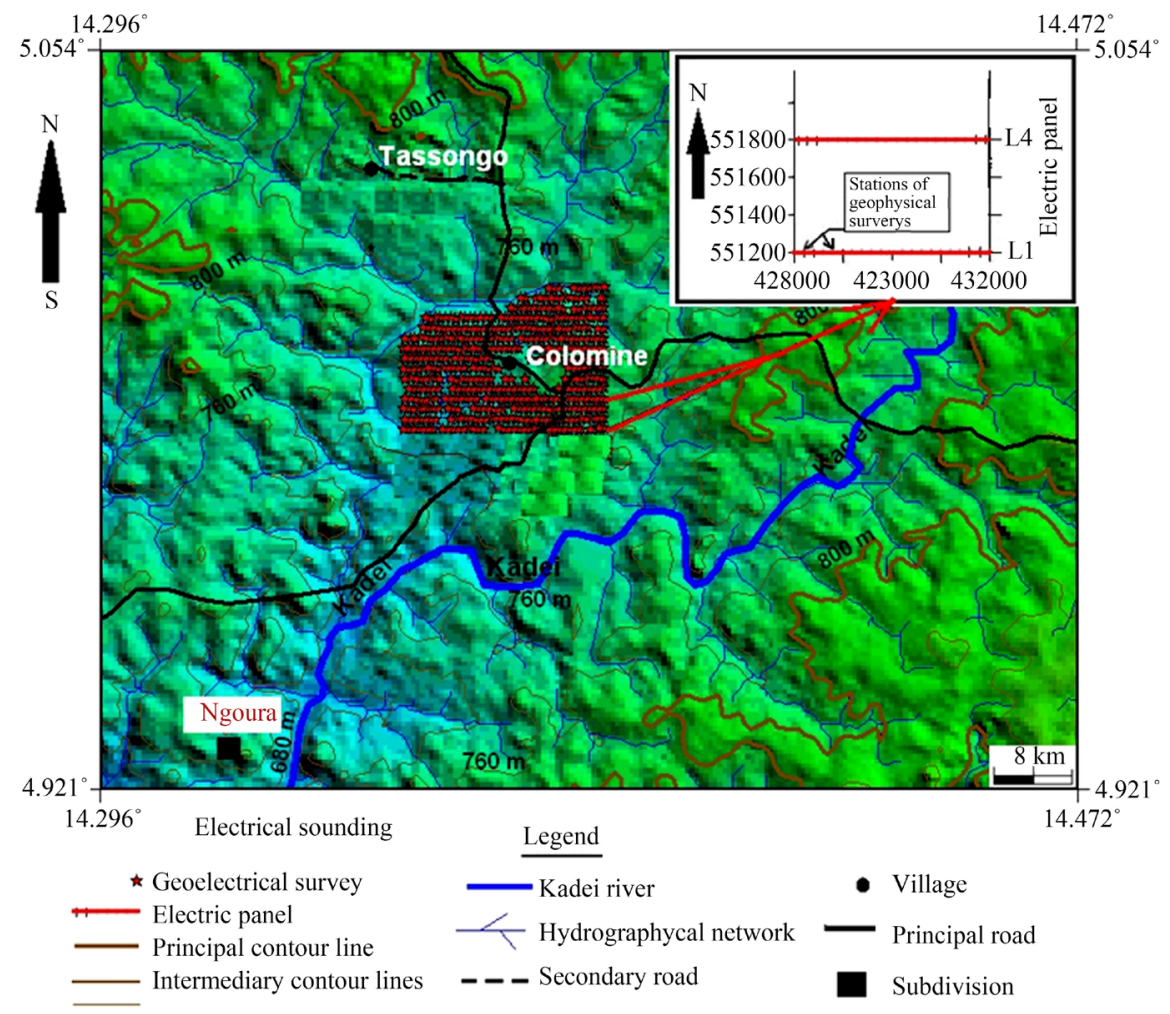

Figure 2. Localization map of the geoelectrical surveys of the study area.

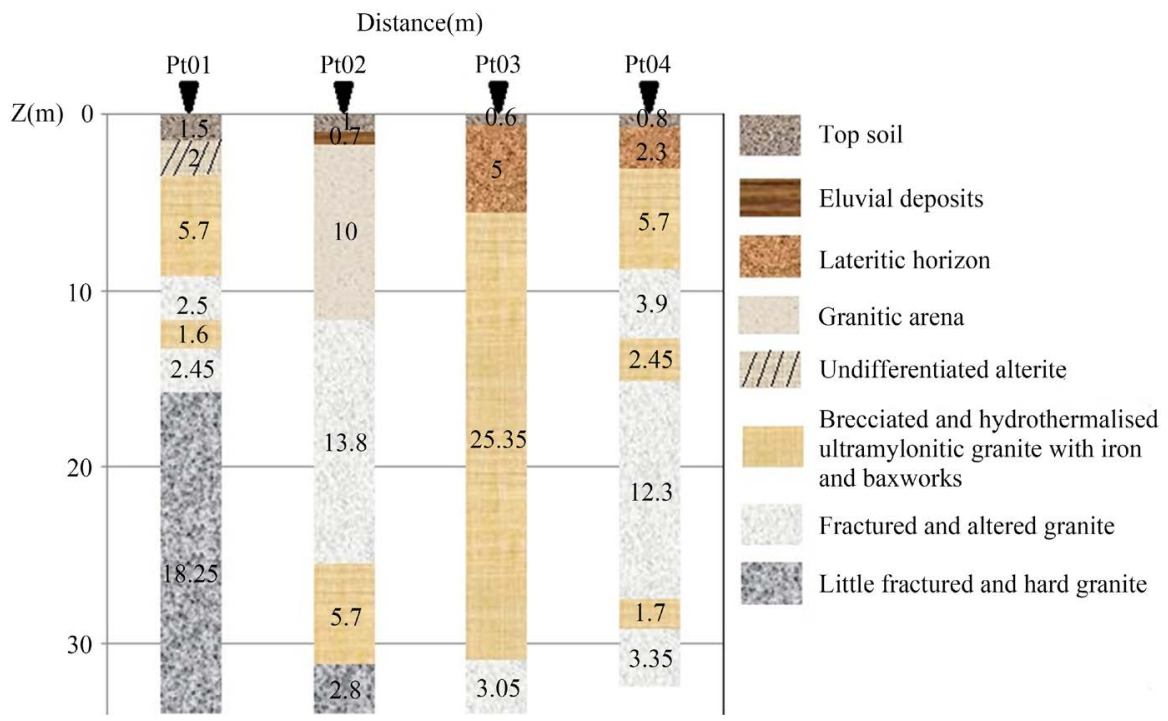

Figure 3. Geological sections of boreholes in the study area from previous work [8].

where potential mineralized bodies can be found. The gold-bearing quartz and pegmatite veins are case studies to this combined approach in the Ngoura subdivision (East Cameroon).

\section{Methods}

\subsection{Direct Current}

The resistivity of materials is a good indicator and parameter for the nature and the weathering. Hence electrical 
prospecting methods have been used for a long time in geological and geotechnical engineering [12] [13]. These methods, both qualitative and quantitative, are based on the Ohm law [12] [13]. They consist in the injection of a direct current in the ground and the measurement of the electrical potential which enables to obtain the true resistivity of encountered formations [12] [13]. In our study area, while considering the geological setting, Schlumberger sounding and profiling methods have been used to determine: the thickness, the lateral extension and the nature of formations encountered along a profile; and to highlight the geometry of geological bodies related to contrasted electrical characteristics [12] [13].

Field electrical methods (DC) consist in injecting an electrical current in the ground between two electrodes A and $\mathrm{B}$, and then, measuring the induced potential drop between two so-called potential electrodes $\mathrm{M}$ and $\mathrm{N}$ [12] [13]. For the current intensity is known and the potential drop measured, it is therefore possible to determine the ground apparent resistivity [13]. This apparent resistivity depends on the current and potential electrodes array. The apparent resistivity $\rho_{\mathrm{a}}$ (Rho) can be expressed as a function of the potential drop and the current intensity [14].

$$
\rho_{\mathrm{a}}=\mathrm{K}\left(\mathrm{V}_{\mathrm{MN}} / \mathrm{I}_{\mathrm{AB}}\right)
$$

where $\rho_{\mathrm{a}}$ is in $\mathrm{Ohm} \cdot \mathrm{m}$, and $\mathrm{K}$ (in $\mathrm{m}$ ) is the geometric factor depending on the electrodes' array which is given by the formulae 2 below.

$$
\mathrm{K}=2 \pi\left(\mathrm{AM}^{-1}-\mathrm{AN}^{-1}-\mathrm{BM}^{-1}+\mathrm{BN}^{-1}\right)
$$

- $\mathrm{V}_{\mathrm{MN}}$ : potential drop between electrodes $\mathrm{M}$ and $\mathrm{N}$, in $\mathrm{mV}$.

- $\mathrm{I}_{\mathrm{AB}}$ : electric current injected between electrodes $\mathrm{A}$ and $\mathrm{B}$, in $\mathrm{mA}$.

For the Schlumberger symmetrical configuration (Figure 4), the apparent resistivity $\rho_{\mathrm{a}}$ is given by Equation (3) as follow [13] [15].

$$
\rho_{\mathrm{a}}=\pi / 4\left(\mathrm{AB}^{2} \mathrm{~V}_{\mathrm{MN}} / \mathrm{MN} \mathrm{I}_{\mathrm{AB}}\right)
$$

This resistivity value enables to characterize a formation at a given position $(\mathrm{O})$ or station (Figure 4). The resistivity of an earth's material depends essentially on the humidity and the clay proportion for a given volume of that material [13] [16]. While clay and water fill in any vacuum in a rock, one assumes that the resistivity is function of parameters such as fracturing, fractures and fissures clay filling in, porosity, the clayey clogging of alluvium [4] [12] [13] [16].

\subsection{Induced Polarization (IP)}

The induced polarization (IP) method ameliorates electrical methods by measuring the apparent chargeability or chargeability M of the earth material [17] [18]. Chargeability enables to assess the earth's capability to accumulate and return an electric current so do a capacitance when currents are injected then interrupted [15] [18]. The chargeability is measured by a ground injection of electric signal gaps (current (I)) using two injection electrodes A and B while the potential drop is measured using two receiving electrodes $\mathrm{M}$ and $\mathrm{N}$ (Figure 4). When IP effects occur, a voltage decreasing curve $\mathrm{Vs}(\mathrm{t})$ is observed at the receiving electrodes $\mathrm{M}$ and $\mathrm{N}$ during current stops between each gap [15] [18].

The chargeability $\mathrm{M}$ is defined as the ratio of secondary voltage $\left(\mathrm{V}_{\mathrm{S}}\right)$ measured at a moment $\mathrm{t}$ after the current stoppage, over the primary voltage $\left(\mathrm{V}_{\mathrm{MN}}\right)$ measured before this break [15] [18].

$$
\mathrm{M}=\mathrm{V}_{\mathrm{S}} / \mathrm{V}_{\mathrm{MN}}
$$

The secondary voltage can be measured at a single point after the stoppage of the current, but it is wise to wait a bit for measurement to be reliable [12] [15]; then the area below the curve can be calculated. The chargeability is given by the formulae below:

$$
\mathrm{M}=1 / \mathrm{V}_{\mathrm{MN}} \int \mathrm{V}_{\mathrm{S}}(\mathrm{t}) \mathrm{dt} \mathrm{t}_{1} \leq \mathrm{t} \leq \mathrm{t}_{2}
$$

It appears that this value is independent of the current injected in the earth. A time dependent transformation is often made in order to enable chargeability values to be comparable from one instrument to another [12] [15]. So, the chargeability expression becomes: 


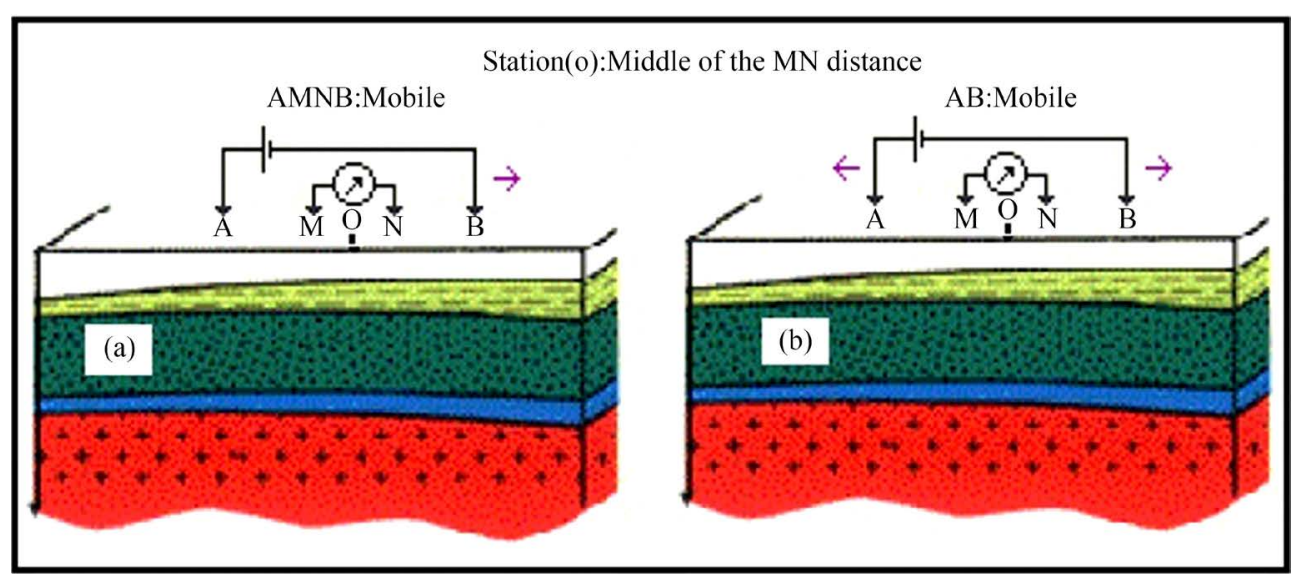

Figure 4. (a) Schlumberger electrical profiling; (b) Schlumberger electrical sounding.

$$
\mathrm{M}=1 / \mathrm{V}_{\mathrm{MN}}\left(\mathrm{t}_{2}-\mathrm{t}_{1}\right) \int \mathrm{V}_{\mathrm{S}}(\mathrm{t}) \mathrm{dt} \mathrm{t}_{1} \leq \mathrm{t} \leq \mathrm{t}_{2}
$$

The chargeability unit is generally $\mathrm{mV} / \mathrm{V}$.

The flow of the electrical current within ground goes along with electrochemical processes whose intensity and characteristics are function of physical and chemical properties of the earth material. This current's flow can follow two patterns as stated by many authors [12] [15] [18].

- By electrical conductibility for which free electrons' motion occurs in metallic particles (pyrite, chalcopyrite, ...);

- By electrical conductibility for which ions' displacement occurs in the fractures and pores fluid contents of rocks

The induced polarization causes electrochemical processes occurring when the current flows from an ionic conductibility medium (water) to an electronic conductibility medium or, from an ionic conductibility medium to a low conductive medium, or with a contact between two different ionic conductibility media [12] [15] [18].

\section{Material and Data Acquisition}

The geoelectrical data acquisition was realized along fifteen profiles following E-W direction. This acquisition is made by combining electrical sounding and profiling through the Schlumberger configuration (Figure 4) along the geophysical profiles [12] [13]. It permits to collect forty-five profiling lines for three Schlumberger configurations $(\mathrm{AB}=100 \mathrm{~m}, \mathrm{MN}=10 \mathrm{~m} ; \mathrm{AB}=200 \mathrm{~m}, \mathrm{MN}=20 \mathrm{~m}$ and $\mathrm{AB}=500 \mathrm{~m}, \mathrm{MN}=50 \mathrm{~m})$ and two electric panels L1 and L4 (Figure 2). The AB maximum length was held at $600 \mathrm{~m}$ to target lithological formations at an approximate depth ranged between 114 and 120 meters [19]. To avoid miscellaneous due to formations’ anisotropies, sounding and profiling surveys were E-W oriented (Figure 2).

We used the direct current resistivity-meter Syscal Junior 48 (IRIS Instrument) system which can run under the Rho \& IP mode, thus enabling simultaneous measurements of the resistivity (Rho) and the chargeability (M) of subsurface structures. Chargeability measurements are sensitive to the induced electromagnetic field fluctuations and sometimes to the local ground resistivity [15] [19]. Thus, electrical data acquisition is made using both the Schlumberger direct method during which the current is injected through A and B electrodes, and the Schlumberger reverse method, for which the current is injected through receiving electrodes $\mathrm{M}$ and $\mathrm{N}$ [16]. The uniqueness of solutions from either of methods above for the same array is governed by the superimposition and the reciprocity principles [16]. The apparent resistivity and chargeability data from Schlumberger profiles were processed and modelled using the Geotomo Res2Dinv software [20] [21] to obtain pseudo-sections or inverse pseudo-sections that reflect the true resistivity and the true chargeability values of subsurface structures studied [20] [21]. The electrical soundings providing the depth distribution of layers for each station (Figure 4) were interpreted using WinSev software from Geosoft [22]. Interpolation of resistivity and chargeability values using Surfer software [23] yielded respective maps which show their spatial distribution in the area under study. 


\section{Results}

\subsection{Resistivity and Chargeability Maps}

Interpolation of electrical dragged data $(A B=500 \mathrm{~m}, \mathrm{AB}=200$ sets $\mathrm{AB}=100 \mathrm{~m})$ has produced resistivity and chargeability maps. They represent apparent resistivity and chargeability isobaths for field trenches exposed at apparent depths of $95 \mathrm{~m}, 38 \mathrm{~m}$ and $19 \mathrm{~m}$ (Figure 5 and Figure 6). These maps help to discriminate areas with conductive anomalies, favorable to tectonic features (faults, fractures or shear zones) to those of polarizability anomalies, favorable to metalliferous disseminations [12] [13] [24] [25].

The resistivity maps presented in Figure 5 show conductive discontinuities zones characterized by low resistivity values (Rho $<1500 \Omega \cdot \mathrm{m}$ ). At $19 \mathrm{~m}$ deep, a conductive zone (dashed blue line) characterized by nearly low resistivity gradients (Rho $<2000 \Omega \cdot \mathrm{m}$ ) covers most of the investigated area. Its extension decreases with depth. It is (surrounded by) resistant area characterized by high resistivity values (Rho $>3000 \Omega \cdot \mathrm{m}$ ) and tightening of iso-resistivity contours. Also, topographic surveys show that this area is of low altitude (Figure 5). It can thus be interpreted as a fracturing zone and alteration of subsurface formations [26] [27]. East of the iso-value maps at all investigated depths (19 m, $38 \mathrm{~m}$ and $95 \mathrm{~m}$ ), a NE-SW conductive anomaly characterized by high resistivity contrast and tightening of iso-contours is observed parallel to the Kadei tectonic line. It was interpreted as a major discontinuity (fracture or fault) and characterized as a major NE-SW tectonic lineament [26] [28]. The iso-resistivity contours of resistant blocks are concentric and discontinuous. They show a N-S discontinuity zone observable at all depths (Figure 5). Moreover, the high resistivity ranges observed in this study, and the works of several authors [7] [24] [27] show that the study area rests on a very strong or granitic basement.

Figure 6 shows the distribution of chargeability at $19 \mathrm{~m}, 38 \mathrm{~m}$ and $95 \mathrm{~m}$ depths, respectively. This distribution characterizes the surface distribution of polarizable disseminated structures for each depth level [18] [29] [30]. The eastside of the three maps shows an anomaly (Figure 6) characterized by high chargeability values and changes in the NE-SW direction. Its extension is assigned to a vein evolution. This anomaly can be interpreted as a high concentration of disseminated metalliferous minerals in a quartz and pegmatite veins [18] [29]-[31]. At all depths, the NW oriented central zone is almost devoid of polarizable structures. It is partly localized in low altitude areas. The low polarization patterns may reveal either the presence of highly fractured

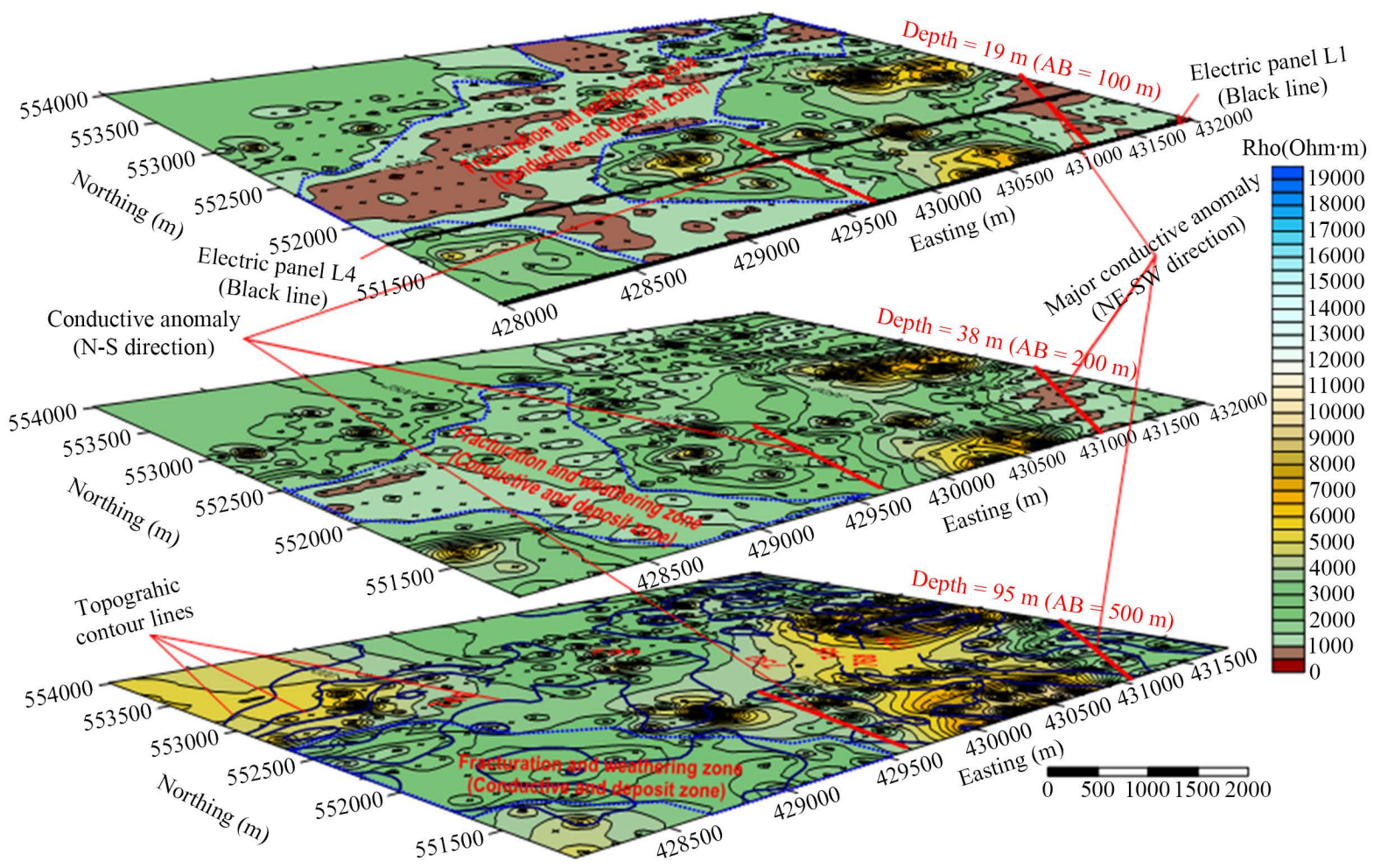

Figure 5. Resistivity maps of $\mathrm{AB}=100 \mathrm{~m}, \mathrm{AB}=200 \mathrm{~m}$ and $\mathrm{AB}=500 \mathrm{~m}$. 


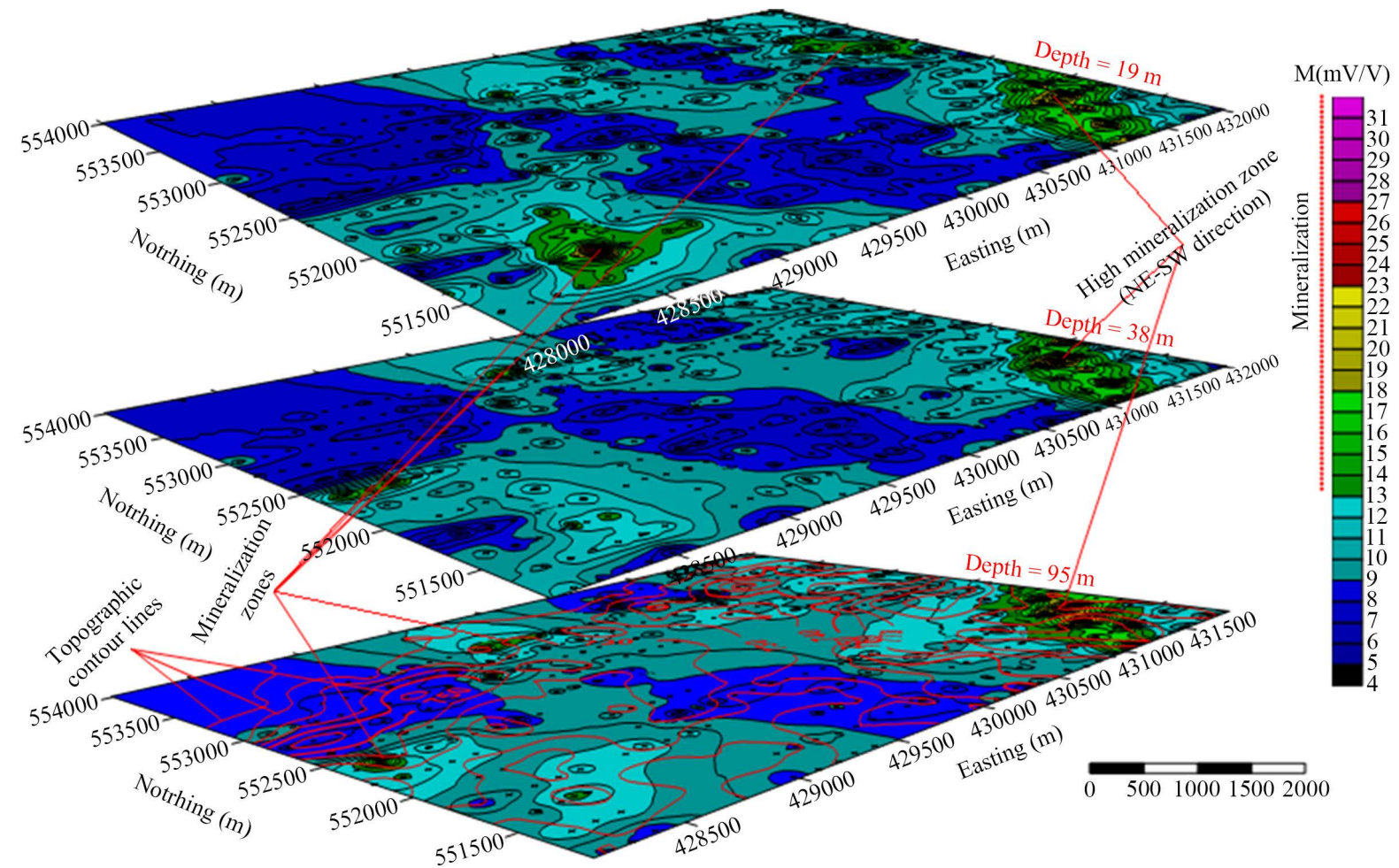

Figure 6. Chargeablility maps of $\mathrm{AB}=100 \mathrm{~m}, \mathrm{AB}=200 \mathrm{~m}$ and $\mathrm{AB}=500 \mathrm{~m}$.

and altered granitic structures or sulfate minerals [31] [32]. At 19 m depth two high chargeability gradient anomalies are clearly visible. Their gradients decrease significantly with depth (Figure 6). They are located in low altitudes areas and may be interpreted as metallic mineral deposits in shallower weathered horizons [12] [30] [31].

The resistivity and chargeability distribution maps (Figure 5 and Figure 6) at specific depths beneath the study area highlight a broad NE-SW major conductive and highly polarizable discontinuity which aligns itself with the Kadéi tectonic line.

\subsection{Pseudo-Sections}

Figure 7 shows the resistivity and chargeability pseudo-inverse sections. They were realized using Res2Dinv software [20] [21] and correspond to the electrical panels along L1 and L4 profiles, respectively (Figure 2 and Figure 5). The depth of investigation for each profile is about $120 \mathrm{~m}$. This depth corresponds to the maximum length of the cable $(\mathrm{AB}=600 \mathrm{~m})$ according to the position xl along a profile [19].

Electric sections in Figure 7(a) and Figure 8(a) show alternating resistant fields (Rho $>2500 \Omega \cdot \mathrm{m}$ ) slightly resistant $(1000<$ Rho $<1500 \Omega \cdot \mathrm{m})$ at surface (depth $<9 \mathrm{~m}$ ). These observed resistivity ranges are attributed to the nature of laterites and sedimentary layers that form the cover of the study area (Figure 1). Less than $60 \mathrm{~m}$ deep and below the sedimentary cover, eleven (11) conductive zones (CZ) were identified (Figure 7(a)). They are characterized by conductive cores (Rho $<1000 \Omega \cdot \mathrm{m})$ and can be interpreted as conductive discontinuities (fractures, faults or shear zones) [12] [25] [26]. The CZ_3 conductive zone extends more than $120 \mathrm{~m}$ (elevations difference) and deep and it is limited between positions $\mathrm{xl}=650 \mathrm{~m}$ and $\mathrm{xl}=1100 \mathrm{~m}$ by sub vertical iso-resistivity contours (Figure 7(a)). It can be interpreted as a major discontinuity, either a fracture or a shear zone [10] [12] [26]. Between positions $\mathrm{xl}=1100 \mathrm{~m}$ and $\mathrm{xl}=2100 \mathrm{~m}$ along profile $\mathrm{L} 1$, most of the crossed subsurface layers are very resistant (with resistivity gradients sometimes greater than 20,000 $\Omega \cdot \mathrm{m}$ ), especially in depth (Figure 7(a)). They seem to have experienced tectonic stresses which are observed as folded and heterogeneous forms displayed by all the iso-resistivity contours [26]. The high resistivity values recorded and the forms of iso-resistivity contours observed (Figure 7(a)) characterize resistant or granitic rocks which have suffered considerable tectonic stresses [12] [26]. 


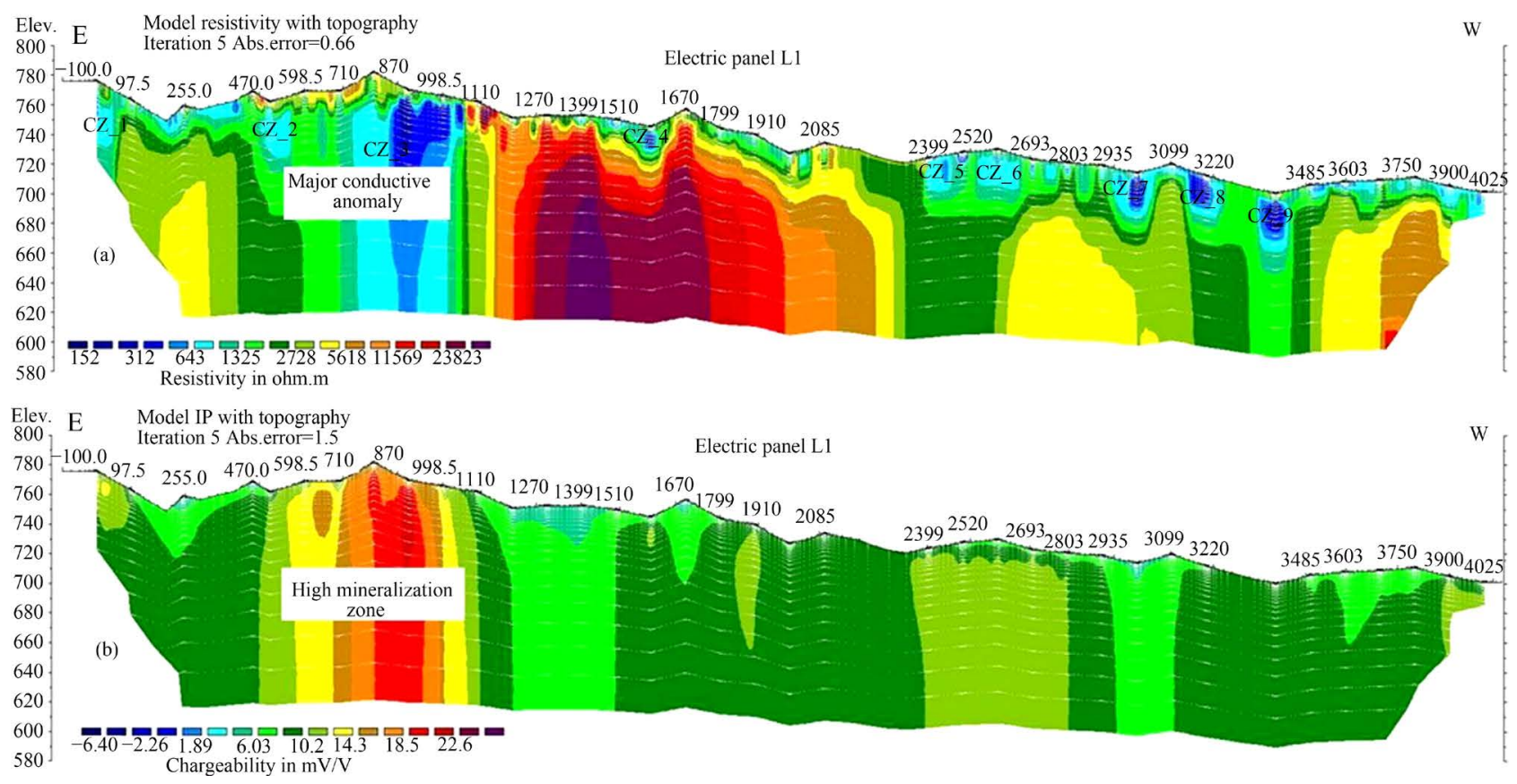

Figure 7. (a) Pseudo-sections of apparent resistivity (electric panel L1); (b) Pseudo-section of chargeability (electric panel L1).

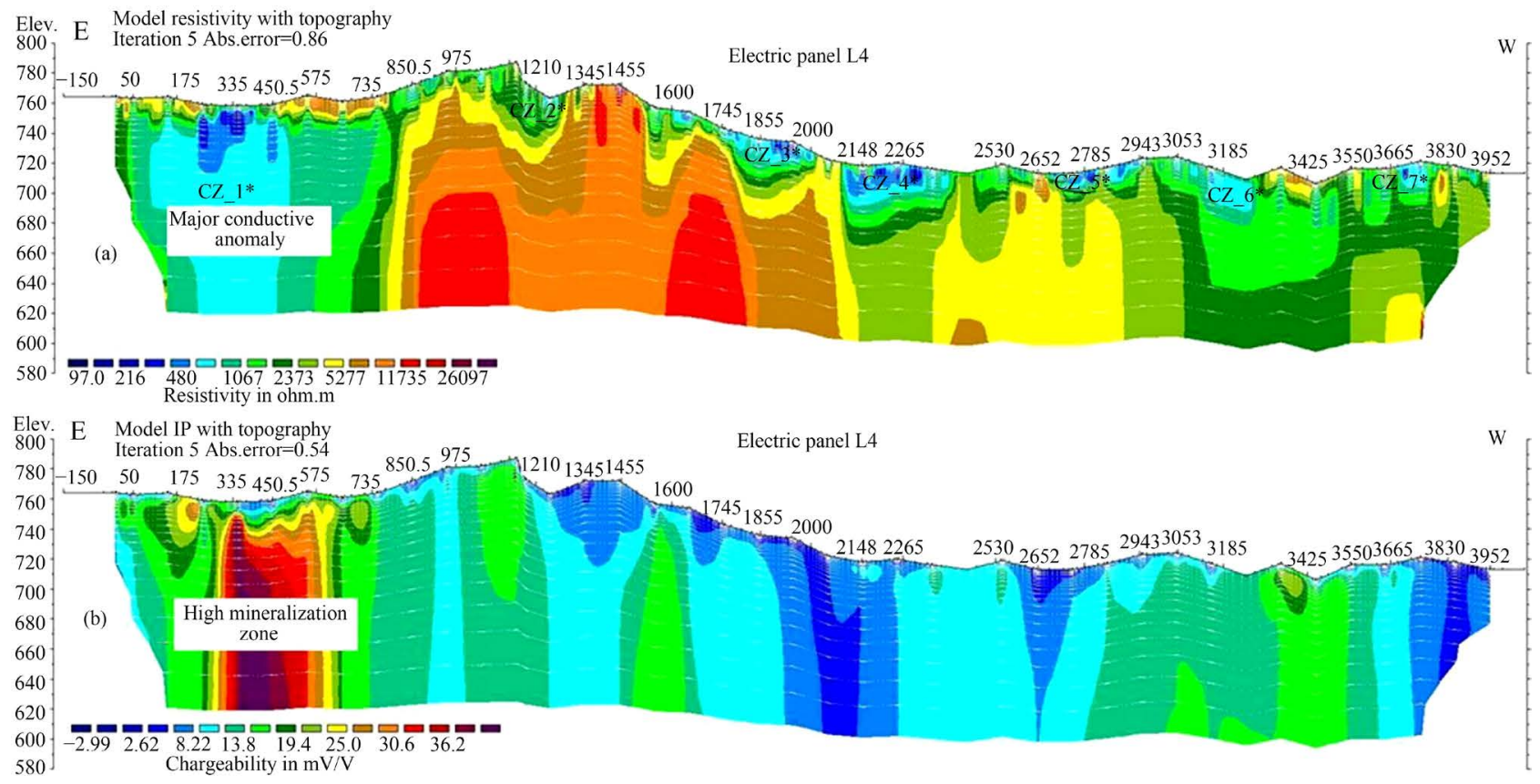

Figure 8. (a) Pseudo-sections of apparent resistivity (electric panel L4); (b) Pseudo-section of chargeability (electric panel L4).

Moving towards the north (Figure 8(a)), the pseudo-section of profile L4 has almost the same geological and structural setting as profile L1. However, an expansion to the west of the CZ_3 conductive zone is noted (between $\mathrm{xl}=50 \mathrm{~m}$ and $\mathrm{xl}=750 \mathrm{~m}$ ). It represents the conductive area $\mathrm{CZ} \_1^{*}$ along profile L4 (Figure 8(a)). It is also noted (Figure 8(a)) on other areas $\left(C Z \_2^{*} \mathrm{CZ} \_3^{*} \mathrm{CZ} \_4^{*} \mathrm{CZ} \_5^{*} \mathrm{CZ} \_6^{*}\right)$ but many of them are extensions of the discontinuities observed along the profile $\mathrm{L} 1$.

The electrical section shown in Figure 7(b) allows to appreciate the distribution of chargeability gradients along the profile L1. One notes to this effect an unbalanced distribution of chargeability gradient (Figure 7(b)). 
The area between the positions $\mathrm{xl}=600 \mathrm{~m}$ and $\mathrm{xl}=1100 \mathrm{~m}$ has a chargeability anomaly characterized by high values [12] [18] [29]. They are attributed to a strong polarization of structures and can be interpreted as a high concentration of metalliferous minerals disseminations in quartz and pegmatite veins [12] [18] [29] [32]. Out of this area, the chargeability gradient is low reflecting a low concentration of disseminated metalliferous minerals or the presence of sulfate minerals [32] [33].

Moving towards the north (Figure 8(b)), the above-mentioned anomaly at profile L1 pass through profile L4 between positions $\mathrm{xl}=50$ and $\mathrm{xl}=750$. The observed gradient is higher. Additionally, along profile L4, three discontinuity zones characterized by chargeability contrasts are observed. They are located between $\mathrm{xl}=1050 \mathrm{~m}$ and $\mathrm{xl}=1350$ between $\mathrm{xl}=1550 \mathrm{~m}$ and $\mathrm{xl}=1750 \mathrm{~m}$ and between $\mathrm{xl}=2950 \mathrm{~m}$ and $\mathrm{xl}=3550 \mathrm{~m}$. They suggest the presence of relatively polarizable particles concentrations disseminated in the basement [12] [18] [29] [32].

\subsection{Geological Sections}

Figure 9 and Figure 10 present the geological sections along profiles L1 and L4. They were realized through the interpretations of sounding curves and geological reconnaissance of outcrops (Figure 1). These sections quantitatively illustrate the lithology of the study area [16] [34].

The spacing of geological columns is $100 \mathrm{~m}$ along profiles L1 and L4 (Figure 9 and Figure 10). This spacing varies in the presence of marshy areas. Geological columns from the eastside of the study area are dominated by thick conductive horizons. These thicknesses confirm the presence of a major conductive anomaly therein [16] [24] [27] that cut profiles L1 and L4 over a deep and lateral extension $115 \mathrm{~m}$ and $600 \mathrm{~m}$ respectively (Figure 9 and Figure 10). Moreover, west of the study area, the profiles display less thick ( $<35 \mathrm{~m})$ conductive horizons (Figure 9 and Figure 10). These horizons are associated to a sandy clay alteration. They show that the western zone is a shallow fracturing zone and deposit of weathered formations. These highlights comfort early results [16] [24] [27]. Conductive or alteration horizons identified by geological sections, can confirm the tectonic accidents (fractures or shear zones) suggested by previous results [12] [25] [27].

\section{Discussion}

Analyze of resistivity and chargeability contrasts through the resistivity and chargeability maps show that spatial distributions of resistivity and chargeability for every underground explored level are not uniform. The resistivity

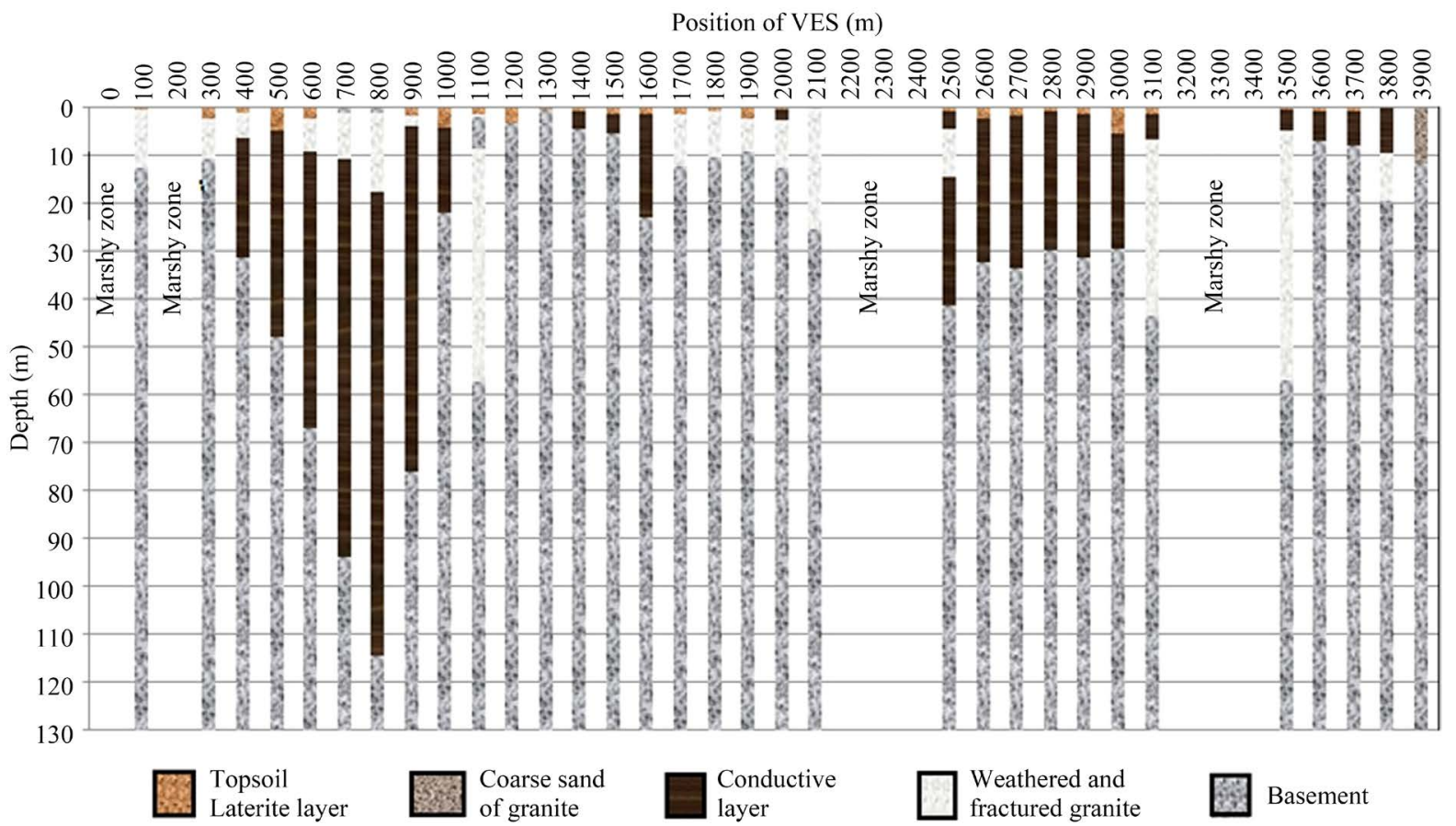

Figure 9. Geological section of electric panel L1, showing probable stratigraphy and formations. 


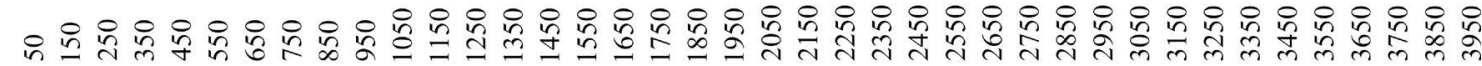

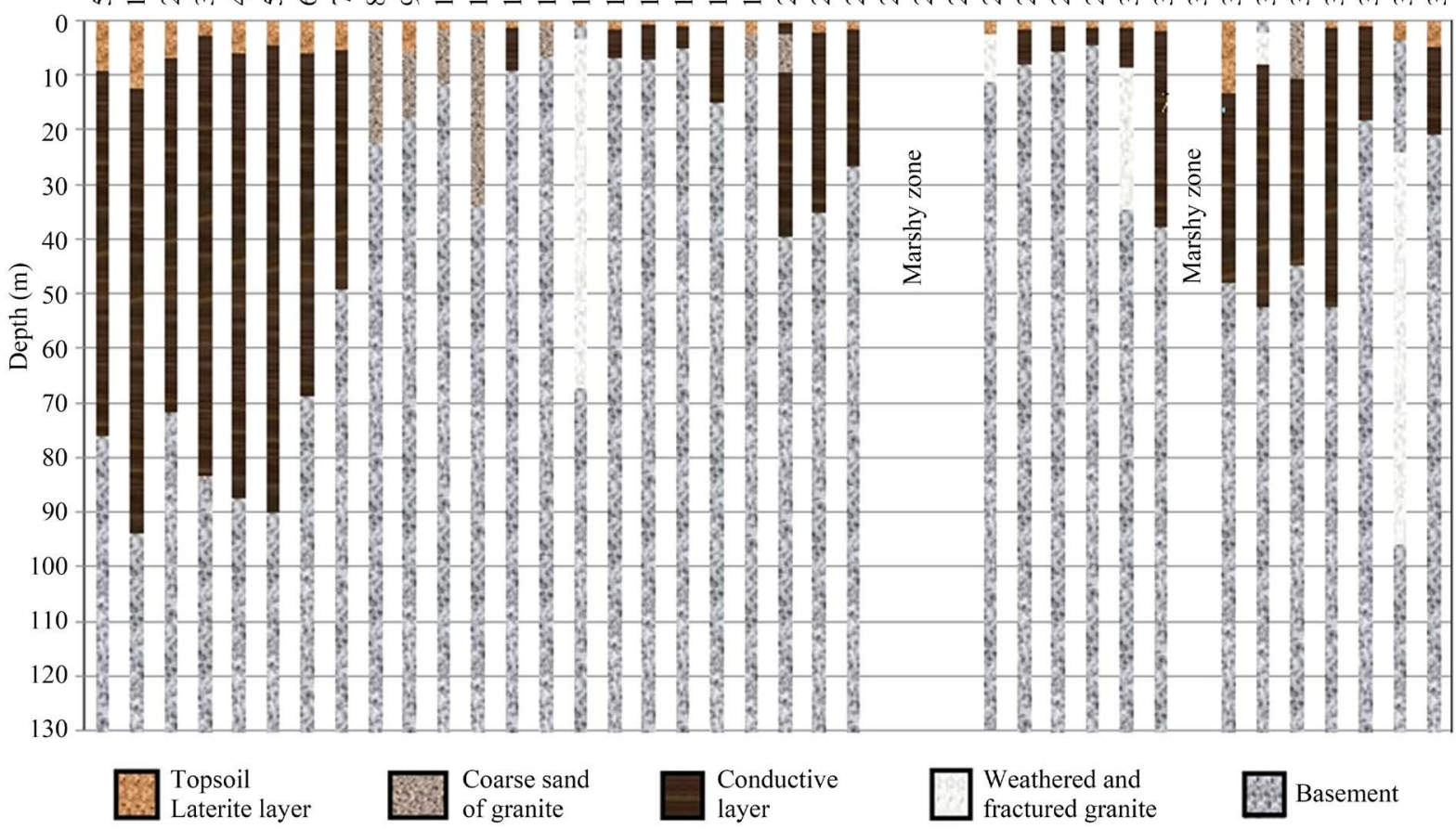

Figure 10. Geological section of the electric panel L4, showing probable stratigraphy and formations.

contrasts highlight conductive horizons that characterize infiltration or mineralogical fluid movements' areas within granitic structures [32] [33]. The greatest output of the study is the mapping of a major highly conductive and mineralized anomaly of NE-SW direction, parallel to the direction of the Kadei tectonic line. The geometrical characteristics (deep and lateral extension) of this anomaly suggest the presence of major anomaly in the study area. Comprehensive studies of this anomaly helped produce two electric panels (Figure 2). They are parallel and of E-W direction (Figure 2). The results obtained through the L1 and L4 pseudo-sections show a highly conductivity and high mineralisation of formations that run along the NE-SW anomaly over a depth extension greater than $120 \mathrm{~m}$ and a lateral extension of about $600 \mathrm{~m}$ (Figure 7 and Figure 8). Also, the results obtained through L1 and L4 geological sections confirm the highly conductive anomaly with a depth and lateral extension of $115 \mathrm{~m}$ and $600 \mathrm{~m}$, respectively (Figure 9 and Figure 10).

This high conductivity characterized by the presence of conductive horizons in depth or superficial alteration, is a good indicator in mining and hydrogeological research works [12] [25] [30]. Actually, in mining and hydrogeological researches, superficial or deep conductive horizons characterize accumulation zones of metalliferous minerals or groundwater [12] [25] [27] [30]. The results of this study show that the Ngoura subdivision's geology is both affected by a fracture zone or a major shear zone and highly mineralized. The strong mineralization characterizes the presence of a high concentration of disseminated metalliferous minerals. Moreover, the eastern region of Cameroon hosts the first choice gold mining activities [1] [8] [25] [35], hence the NE-SW anomaly highlighted in this study is somewhat a considerable potential auriferous quartz or pegmatite vein. The results of this study are in line with the geological and tectonic work carried out in the region [2] [3] [7]-[10] also marked by the NE-SW Kadei tectonic line.

\section{Conclusion}

A combined approach involving geoelectrical DC resistivity and IP methods was used as geophysical tool in the investigation of subsurface structures in the Ngoura subdivision (East Cameroon). Field data acquisition was carried out with a Syscal Junior 48 resistivity-meter. The interpretations of the collected data helped to highlight parallel to the NE-SW Kadei tectonic line, a major conductive and highly mineralized lineament (fracture or 
shear zone). This strong mineralization characterizes the presence of a great concentration of disseminated metalliferous minerals. The mining reconnaissance works in the area and several authors have characterized this anomaly to a gold quartz vein or extended pegmatite veins. This information is in line with the geological and tectonic setting of the region marked by NE-SW Kadei tectonic line. Thus, the present study supports the combination of IP and DC geoelectrical methods as a potential approach to the identification of mineralized bodies.

\section{Acknowledgements}

The authors are grateful to the reviewers for their kind remarks making the manuscript clearer and more pertinent. The authors are also grateful to the Artisanal and Small Scale Unit of the Ministry of Mines, Industry \& Technological Development for providing the Syscal Current Iris instrument to collect the data sets on site.

\section{References}

[1] Kim, S., Yoon, M.J., Kim, S.G. and Kwon, D.J. (2009) Exploration Report Colomine Placer Gold Project Cameroon. Geotech Consultant Co., Ltd., Seoul, 87.

[2] Cornachia, M. and Dars, R. (1983) Un trait majeur du continent africain. Les Linéaments Centre africains du Cameroun au Golfe d'Aden. Bulletin de la Societe Geologique de France, 7, 102-109.

[3] Rolin, P. (1995) La zone de décrochement panafricain des Oubanguides en République Centrafricaine. Comptes Rendus de l'Académie des Sciences, Paris, 320, 63-69.

[4] Mvondo, H., Den-Brok, S.W.J and Mvondo-Ondoa, J. (2003) Evidence for Symmetric Extension and Exhumation of the Yaoundé Nappe (Pan-African Fold Belt, Cameroon). Journal of African Earth Sciences, 35, 215-231. http://dx.doi.org/10.1016/S0899-5362(03)00017-4

[5] Mvondo, H., Owona, S., Mvondo-Ondoa, J. and Essono, J. (2007) Tectonic Evolution of the Yaoundé Segment of the Neoproterozoic Central African Orogenic Belt in Southern Cameroon. Canadian Journal of Earth Sciences, 44, 433444. http://dx.doi.org/10.1139/e06-107

[6] Olinga, J.B., Mpesse, J.E., Minyem, D., Ngako, V., Ndougsa-Mbarga, T. and Ekodeck, G.E. (2010) The Awaé-Ayos Strike-Slip Shear Zones (Southern-Cameroon): Geometry, Kinematics and Significance in the Late Panafrican Tectonics. Neues Jahrbuch für Geologie und Paläontologie, 257, 1-11.

[7] Regnoult, J.M. (1986) Synthèse géologique du Cameroun. DMG/MINMEE, 119 p.

[8] Vairon, J., Edimo, A., Simeon, Y. and Vadala, P. (1986) Protocole d'accord "pour la recherche des minéralisations d'or dans la province aurifère de l'Est” Cameroun. Rapport du BRGM, Mission or Batouri, deuxième et troisième phase, $251 \mathrm{p}$.

[9] Gazel, J. and Giraudie, C. (1965) Notice explicative sur la région Abong-Mbang Ouest de la carte géologique de reconnaissance. Mémoire du BRGM, No. 92. Dir. Mines et Géol., Cameroun, 29 p.

[10] Meying, A., Ndougsa-Mbarga, T. and Manguelle-Dicoum, E. (2009) Evidence of Fractures from the Image of the Subsurface in the Akojolinga-Ayos Area (Cameroon) by Combining the Classical and the Bostick Approaches in the Interpretation of Audio-Magnetotelluric Data. Journal of Geology and Mining Research, 1, 159-171.

[11] Ndougsa-Mbarga, T., Meying, A., Bisso, D., Layu, D.Y., Sharma, K.K. and Manguelle-Dicoum, E. (2011) Audiomagnetotellurics (AMT) Soundings Based on the Bostick Approach and Evidence of Tectonic Features along the Northern Edge of the Congo Craton, in the Messamena/Abong-Mbang Area (Cameroon). Journal of Indian Geophysical Union, 15, 145-159.

[12] Keary, P. and Brooks, M. (1991) An Introduction to Geophysical Exploration. 2nd Editions, Blackwell Scientific Publications, Oxford, $254 \mathrm{p}$.

[13] Parasnis, D.S. (1997) Principles of Applied Geophysics. 5th Edition, Chapman and Hall, London, 104-176.

[14] Ward, S.H. (1990) Resistivity and Induced Polarization Methods. In: Ward, S.H., Ed., Geotechnical and Environmental Geophysics, Vol. 2, Society of Exploration Geophysicists, Tulsa, 147-190.

[15] Kiberu, J. (2002) Induced Polarization and Resistivity Measurements on a Suite of near Surface soil Samples and Their Empirical Relationships to Selected Measured Engineering Parameters. MSc Thesis Submitted at ITC, Enschede.

[16] Chapellier, D. (2000) Prospection électrique en surface. Cours de géophysique. Université de Lausanne, Institut Français de Pétrole, Lausanne, 98 p.

[17] Fink, J.B., McAlester, E.O., Sternberg, B.K., Ward, S.H. and Wieduwilt, W.G. (1990) Induced Polarization, Applications and Case Studies. Society of Exploration Geophysicists, Tulsa, 414.

[18] Sumner, J.S. (1976) Principles of Induced Polarization for Geophysical Exploration. Elsevier, Amsterdam, 227. 
[19] Loke, M.H. (2000) Electrical Imaging Surveys for Environmental and Engineering Studies: A Practical Guide to 2-D and 3-D Surveys. 61.

[20] Loke, M.H. (2010) Res2Dinv ver. 3.59 for Windows XP/Vista/7, 2010. Rapid 2-D Resistivity \& IP Inversion Using the Least-Squares Method. Geoelectrical Imaging 2D \& 3D Geotomo Software 2010, Malaysia.

[21] Loke, M.H. and Barker, R.D. (1996) Rapid Least-Squares Inversion of Apparent Resistivity Pseudosections by a Quasi-Newton Method. Geophysical Prospecting, 44, 131-152. http://dx.doi.org/10.1111/j.1365-2478.1996.tb00142.x

[22] Jenny, J. and Borreguero, M. (1999) Winsev 5, 1-D Inversion Software.

[23] Dickenson, K. Surfer Version 9.00, Surface Mapping System Copyright (C 1993-2009. Golden Software, Inc., Golden.

[24] Telford, W.M., Geldart, L.P., Sheriff, R.E. and Keys, D.A. (1990) Applied Geophysics. 2th Edition, Cambridge University Press, Cambridge, 770. http://dx.doi.org/10.1017/CBO9781139167932

[25] Tijani, M.N., Osinowo, O.O. and Ogedengbe, O. (2009) Mapping of Sub-Surface Fracture Systems Using Integrated Electrical Resistivity Profiling and VLF-EM Methods: A Case Study of Suspected Gold Mineralization. RMZ-Materials and Geoenvironment, 56, 415-436.

[26] Louis, I.F., Raftopoulos, D., Goulis, I. and Louis, F.I. (2002) Geophysical Imaging of Faults and Fault Zones in the Urban Complex of Ano Liosia Neogene Basin, Greece: Synthetic Simulation Approach and Field Investigations. Journal of Electrical \& Electronics Engineering, Special Issue, 269-285.

[27] Gouet, D.H., Ndougsa-Mbarga, T., Meying, A., Assembe, S.P. and Man-MvelePepogo, A.D. (2013) Gold Mineralization Channels Identification in the Tindikala-Boutou Area (Eastern-Cameroon) Using Geoelectrical (DC \& IP) Methods: A Case Study. International Journal of Geosciences, 4, 643-655. http://dx.doi.org/10.4236/ijg.2013.43059

[28] Singh, S.B. and Stephen, J. (2004) Deep Resistivity Sounding Studies in Detecting Shear Zones: A Case Study from the Southern Granulite Terrain of India. Journal of Asian Earth Sciences, 28, 55-62. http://dx.doi.org/10.1016/j.jseaes.2004.09.014

[29] Holliday, J.R. and Cooke, D.R. (2007) Advances in Geological Models and Exploration Methods for Copper \pm Gold Porphyry Deposits. Ore Deposits and Exploration Technology, Paper 53, 791-809.

[30] Salmirinne, H. and Turunen, P. (2007) Ground Geophysical Characteristics of Gold Targets in the Central Lapland Greenstone Belt. Geological Survey of Finland, Special, Paper 44, 209-223.

[31] Meju, M.A. (2002) Geoelectromagnetic Exploration for Natural Resources: Models, Case Studies and Challenges. Surveys in Geophysics, 23, 133-205. http://dx.doi.org/10.1023/A:1015052419222

[32] Campbell, D.L. and Fitterman, D.V. (2000) Geoelectricalal Methods for Investigating Mine Dumps. Proceedings of the 5th International Conference on Acid Rock Drainage (ICARD 2000), Denver, 21-24 May 2000, 1513-1523.

[33] Dahlin, T., Rosquist, H. and Leroux, V. (2010) Resistivity-IP Mapping for Landfill Applications. First Break, 28, 101105.

[34] Tahmasbinejad, H., Hoseini, F.Z., Mumipour, M., Kaboli, A. and Najib, M. (2012) Delineation of the Aquifer in the Curin Basin, South of Zahedan City, Iran. The Open Geology Journal, 6, 1-6. http://dx.doi.org/10.2174/1874262901206010001

[35] Wippern, J. and Seyferle, W. (1966) Travaux de Recherche des gisements d’or de Bétaré-Oya (Cameroun). Rapport IPCO, 73. 


\section{Submit or recommend next manuscript to SCIRP and we will provide best service for you:}

Accepting pre-submission inquiries through Email, Facebook, LinkedIn, Twitter, etc.

A wide selection of journals (inclusive of 9 subjects, more than 200 journals)

Providing 24-hour high-quality service

User-friendly online submission system

Fair and swift peer-review system

Efficient typesetting and proofreading procedure

Display of the result of downloads and visits, as well as the number of cited articles

Maximum dissemination of your research work

Submit your manuscript at: http://papersubmission.scirp.org/ 